\title{
When the Future Disappears: \\ The Modernist Imagination in Late Colonial Korea. Janet Poole. New York: Columbia University Press, 2014.
}

A lucid study of Korean literary history during the colonial period seems almost impossible, especially during the politically oppressive "dark period" (amhŭkki), from the late 1930s to the early 1940s. As Janet Poole outlines in her book's introduction, the problem of "triple censorship"- by the Japanese colonial authority, and the ideologically divided two Koreas after liberation-will always cast a shadow in the reading of colonial Korean writers' works. Poole's book sheds a ray of light by focusing on the theme of a disappearing future in late colonial modernist works. The fading future of Korea and Koreanness is articulated in several experiments until, ultimately, the work is literally not in Korean, but in Japanese. However, Poole reminds the reader to distinguish what is literary and literal. What must be examined is the writer's language within the national language - whether it is Korean or Japanese. What matters is not to search word-for-word for what is missing, but how the writers were able to pass on their meanings in the rhetorical. Poole sets out to do exactly that, by choosing to write on the "productivity of [the] silence" rather than "impose substitutes or presume

* Professor, Department of Foreign Language \& Humanities, Los Angeles City College 
what a writer 'really' wanted to say" (16).

Chapter 1 is centered on Ch'oe Myŏngik's (1903-?) "Walking in the Rain" (1936). Poole notes several features and methods that make the bleak future of Korea acutely felt in the story. The "photographic tale" is set in a portrait studio, and the story ends with the death of the photographer. The photography of P'yŏngyang and its residents represent the life of the urban petite bourgeoisie at the time. Photos are freeze frames of the present-mementos for the future, to reminisce about the past. What Ch'oe documents is not always picture perfect as it is seen through Pyŏngil. The depiction of the city alleys on Pyŏngil's route is less than "postcard aesthetic" (24). Pyŏngil might "have little faith in turning time "upside down" (17) but he is a camera obscura that shows the "upside down" image of what seems to be true about progress and the future. The photographer who is saving money for the future dies of typhoid, making his effort pointless. The details of quotidian life "disrupt the forward moving narrative of modernization" (38).

Chapter 2 explores the motif of nostalgia, concentrating on the writings of philosopher Sŏ Insik (1906-?). In the crisis of future which is either inconceivable or too painful to envision, contemplating the past becomes a coping mechanism. If to be modern is a way of overcoming colonialism, to suffer from nostalgia, what Svetlana Boym claims "a disease of the modern age," was a new "way of being universal" (54). Poole notes, "Sǒ's definition of nostalgic longing constructs a relationship between past and present that refuses to trust the linear time of continuity and progress" (57). Longing for the past that is lost becomes an act of metaphysical possession. In "The Beauty of Longing and Decadence," Sŏ declares "When we submerge ourselves in the memories of something old that has been lost, the past returns again to the present like a phantom. Only memories can be mine eternally. No power on earth can steal those memories of old things that rise in our emotional world" (57). The objects with which Sŏ attempts to recapture are tradition, a "temporal concept," and the East, a "spatial form."

How Yi T'aejun's essays create a microcosm of a "private orient" by 
delving into antiquity is discussed in Chapter 3. Yi's preoccupation with "feudal nostalgia" is beyond a "form of escape and a refusal to confront the contradictions of the present by submerging oneself in a love of old objects" (85). It is unclear if Yi's intent was to subvert colonial powerthe exoticization and idealization elevating the Orient and antiquity above the modern and the West which the Japanese tried to imitate. The striking antithesis in Yi's Eastern Sentiments (1941) reveals Manchuria embodying both "cosmopolitan modernity" and "endless farmland" (111). Ironically, $\mathrm{Yi}$ is able to fantasize himself as "a lonely shadow on the endless plain" because he identifies with the White Russian waitresses on the Asia Express dining car, "without even a homeland to embrace with their homesickness." (111) Yi's antiquarianism could also be argued as "that of a dilettante indulging himself, a scandalous turning away from the political and social pressures of his time" or as he tried to defend after liberation, an attempt to "save the traces of an honorable Korean cultural past" (113). Poole concludes Yi's travelogue as simply a literary and historical artifact when a "Confucian literati" was displaced in an imperialist capitalist regime.

The space of "peri-urb" is surveyed in Chapter 4, beginning with the urban planning development of Seoul to Kyŏngsŏng/Keijō. The city’s overhaul included major expansion and reorganization of boundaries. The works of Yi T'aejun, Pak T'aewŏn (1910-86), and O Changhwan (191851) are cited to illustrate the new peri-urban landscape. The most symbolic structure that appears repeated is the City Wall (Sŏngbyŏk). In 1914, Seoul was a "smallish city with a population of a quarter of a million" (119), but thirty years later, that number quadrupled with rural migration and Japanese settlers: "the city was literally breaking out of its walls" (120). The wall is a constant reminder for those who live outside, how they are excluded to the fringe of the city while the Japanese settler can afford housing within the walls. The walls no longer delineate the boundaries of the city but the "meaning of the city walls" (130) cannot be eliminated. The walls "thrive for ten thousand years as generations change" (125) in O's poem and in Yi's essay, a true "artwork, their 
beauty stemming from passing beyond functionality" (128).

Chapter 5 is exclusively about literary critic Ch'oe Chaesŏ (1908-64) and his collection of essays Korean Literature in the Age of Transition [Tenkanki no Chōsen bungaku] (1943). Ch'oe, a colonial subject writing in Japanese, fully supporting the war mobilization can be disturbing to understand, but Poole interprets Ch'oe's logic: "the powerful attraction and comfort offered by the possibility of becoming Japanese" (149). Poole investigates how Cho'e's literature written in Japanese embodies his logics of incorporating into the rhetoric of the co-prosperity sphere of East Asia. The fall of Paris to Hitler's Germany declared a "new European order" (152), and it was a shock for Ch'oe who realized that the only future that is imaginable for Korea is as Japan via imperialization. "When Ch'oe discusses the concrete literary policies of kokumin bungaku (national literature), the loss of writing in Korean is more than recompensed by the possibility of liberating oneself from the restrictions that come with being Korean within the Japanese empire" (172). Ch'oe's new view of the Japanese empire as a "nation without centers" is to envision Japan sprawling beyond Korea (Asia). Within that vast empire, according to Ch'oe, Korea would not be a colony but a region, and he compares Korea to Scotland in the United Kingdom. "Likening Korean literature to that of Scotland raised the prospect of Korean literature being considered an integral part of a Japanese national literature, thus adding 'richness' to its metropolitan partner. Henceforth Korea would not have to be a margin but an equal part of the center" (173) — not a bad trade-off for writing in Japanese. Thus, Ch'oe urged young Koreans to find meaning in their lives by sacrificing themselves to the cause of the war, and he encouraged Korean writers to glorify the emperor and the empire. In Ch'oe's case, the anxiety of the unknown future as a colonial Korean was too much to bear, and he participated in a future that is at least promising as a kokumin, an imperial-national.

The last chapter further deals with other writers who wrote in Japanese and the politics of Korean writers making the choice over language. The background of language policy in colonial Korea helps the reader to 
observe the political climate of the time as the pressure intensified for writers to produce works in Japanese in order to be published. By the 1940s, "Korean culture was now considered a region of Japan, and the Korean language, a dialect" (188). She shows that Korean culture was recognized as a regional culture within the multi-ethnic Japanese empire while the Korean language became a dialect of the empire. Kim Namch'ŏn's “One Morning” (“Aru asa”) (1943) is in the spotlight to answer the question "Was it possible to take possession of the imperial language without being possessed by the spirit of the emperor?" (188).

Poole's outlook of her subject is complex and subtle-she tries to explain how writers convey the experience of time when the future for Korea was dismal to non-existent. The writers' sense of time manifests in different styles and techniques. The book reminds us that even under the worst of political oppression, writers still have the skills to express themselves and their particular time and place, despite the hopeless future. Poole reminds us, "We can only honor them by reading their work, keeping in mind perhaps that what little we know about what later came to pass, but bearing in mind also that what was believed possible at one moment also matters, even if its future remained only on a printed page" (207).

Poole has chosen to research literature at a particular time that was extremely desperate and anxious for Korean writers. The works are not comforting or entertaining. The weight of the historical and political context forces the present reader to be constantly conscientious of the writers' limitations. Poole has done an outstanding job in reminding us that it is actually the restraint of censorship that challenged the writers, and its what "makes colonial writing most literary, as it demonstrates in an intense fashion the qualities that already mark literary language" (16). 